\title{
OUTSOURCING IN REVERSE LOGISTICS
}

\author{
Janusz Grabara,PhD, grabara@zim.pcz.pl \\ Czestochowa University of Technology, Management Faculty
}

\begin{abstract}
Nowadays cost reduction is a fundamental strategy used in companies during fighting for survival, keeping or increase in sales levels and profits. More and more often observed tendency to concentrate commercial and production companies leads to rise of demand for outsourcing in a reverse logistics chain.
\end{abstract}

\section{Concept of outsourcing of logistics services}

A strategy commonly termed 'outsourcing' is nothing more than a subcontracting, to a specialized companies, a part of functions and processes previously performed on your own. The scope of operations encompassed by outsourcing is becoming wider and wider. The subcontracting concerns e.g.: transport and forwarding (organizing of transport by the shipper), advertising, market survey, security services, social facilities (holiday and sport facilities), health care, legal services, training, financing of transactions, banking services and contract insurance. Outsourcing concerns exclusively services. There are two forms of outsourcing:

- external (isolation)

- internal (separation) - strategic outsourcing.

In case of isolation, an economically independent and outside (in legal terms) service provider, on the basis of the contract, accepts a part of the functions from its client. With this solution a company which subcontracts the outsourcing has little influence on the services. In case of separation, the function of the outsourcing is passed to the independent, but capital-bound, service provider. In case of this solution the function of the outsourcing is passed to a daughter company cooperating directly or to a company where the company in question has its shares. Daughter company is a legally independent entity, however, all its own capital derives from mother company and the operation of such company is subordinate to the decisions of superior company. Among cooperating companies there is a group of economically and capital-independent entities, which create a service company together, whose aim is to provide outsourcing services. Establishment of a company in which the production or commercial company and logistics provider have their shares consists in transferring, from the service provider a necessary know how and a capital while the client company guarantees cooperation ${ }^{1}$. This form of cooperation enables outsourcing services to be controlled through the company which subcontracts the services.

Outsourcing of logistics services may take a variety of sizes and shapes. In its most extreme form it leads to total liquidation of own logistics system and taking on responsibility for logistics management by external operator.

In logistics outsourcing the lead is taken by international operators with necessary competence in terms of logistics strategic consulting and the execution potential connected with the branch experience. The operator must ensure their customers as best services as possible at the

\footnotetext{
${ }^{1}$ W. Rydzkowski, Ustugi logistyczne (Logistics Services), Instytut Logistyki i Magazynowania, Poznań 2004.
} 
competitive price. In Polish market two following groups of logistics services can be characterized:

- transport services, which should be treated as fundamental services resulting from the necessity to move things and persons from one place to another, between the source and the goal, with the limited scope of consulting, which might concern, in case of e.g. international deliveries, the most favourable supply base. Relocation- transport is an activity performed in order to satisfy particular needs, which requires to cover the distances either by a person or by goods in order to satisfy such needs. ${ }^{2}$

- forwarding services, which, in its fundamental form consist in organization of the transport processes, insurance, preparation of necessary documentation and customs services. More advanced shipping services, which bring great cost benefits in case of general cargo or pallet cargo (as opposed to full truck load), include services provided by the consolidated shippers on the basis of the network of several or more than ten terminals, which consists in consolidation or deconsolidation of a particular cargo, custom packaging, with warehousing option and in more modern version of cross docking and thus in transition of cargo through terminal (without warehousing) and stopping their movement only for the time necessary for order picking, changes in cargo shape and changes in means of transport.

- logistics services, which, apart from transport and forwarding activities, encompasses terminal services, starting from cross-docking, through warehousing to order picking (including picking and packaging) and additional activities: labelling, re-packing, foil packing, minor repairs, creation of promotional sets etc. (sometimes referred to as copacking). Moreover, logistics companies often control their clients' inventory, undertake complex servicing of distribution or logistic consulting - reaching far more than a selection of the route for deliveries or a supply base. The basis for creation of logistics services is to own a wide area computer network which might be connected with a client's network in a variety of configurations ${ }^{7}$.

A company, which intends to subcontract logistics services to another external company should realize that they will partially or totally lose control over some processes connected with logistics. A considerable role is played by successful cooperation based on partnership of both companies and mutual trust. ${ }^{3}$

In order for this goal to be achieved, companies often abandon performance of various traditional activities e.g. legal services, research, pay policy, accounting services through transfer of these service to specialized external companies. Such a policy enables company to focus their assets and efforts on what they can do best, e.g. on production, commercial activity or providing the services. Many companies which need to reduce its organizational structure finds logistics to be an activity, which can be disposed of in order to reduce costs and to improve the customer service.

While highlighting the concept of outsourcing one should consider what makes the companies order logistics activities from specialized external services. The reasons for such activities are numerous, however, the most important include the need for having logistics activities performed in best way as possible, which is possible in case of these activities being

\footnotetext{
${ }^{2}$ T. Szczepaniak, Transport $i$ spedycja $w$ handlu zagranicznym (Transport and Forwarding in International Trade), PWE, Warsaw 2002.

${ }^{3}$ W. Rydzkowski, Ustugi logistyczne (Logistics Services), Instytut Logistyki i Magazynowania, Poznań 2004.
} 
performed by a specialized entities with appropriate infrastructure and capacity which enable logistics services to be provided on possibly highest level. Thus it seems that the argument for such a cooperation is lack of workload within the company which can focus on its core activities as well as easiness of flexible response to any changes within its environment. The advantages concern also economical aspect, through reduction in costs and service area both inside the company as well as services for customers. Obviously, such a solution has particular disadvantages due to the possibility to be dependent on external service provider as well as loss of own know-how in terms of technology and logistics knowledge. Therefore, a company which makes a decision on outsourcing should consider arguments both for and against it. Main factors for outsourcing include: $^{4}$

- the costs related to logistics activity are clearer, mainly through easiness of their recording,

- cost reduction is possible through selection of most competitive offer in the market, which enable more flexible use of the owned resources,

- levelling of internal problems which make performance of tasks difficult.

The arguments against implementation of outsourcing include: ${ }^{5}$

- probability of being dependent on service provider,

- risk of deterioration in quality of own products (e.g. improperly transported),

- necessity of exact calculations in terms of costs, especially in the aspect of cost reduction,

- lack of possibility to use experience in logistics obtained during operation in the market.

The companies who decide to subcontract logistics activities outside focus more on coordination of operation within the area of cooperation with service provider and they can organize their logistics system so that it functions more efficiently within the chain. The solutions for organization of logistics processes enable formation of such structures which will enable using of all advantages of the described solutions. It should be considered if the companies are able to form their logistics chains so that all logistic activities and processes connected with their coordination are performed in a way that enables formation of an efficient structure adapted to the needs so that the achievement of the predefined goal of logistically managed organization is possible, i.e. finding right customers and ensuring them availability of the offered goods. From the company's point of view the processes should be efficient both organizationally and economically.

The processes which occur in contemporary economy indicate evolution, leading to the situation in which traditional divisions which separated production, commerce and service companies are fading away. More and more often logistics systems of separated companies are being replaced by whole logistics systems of logistics chains. The definition of the essence of logistics activities is becoming more and more difficult, mainly due to the fact of faded borders between companies. Evolution of outsourcing leads to the situation where instead of normal subcontracting of services such as transport or warehousing a so called third party, and even the fourth-party logistics, is implemented for virtually total acquisition of the logistics area. The concerns may arise if employing external service provider, particularly a close cooperation with them, do not lead to losing control over the processes, which is very important as the companies which provide outsourcing services are on the supplier-customer interface. Thus, they should

\footnotetext{
${ }^{4}$ Duck O., Schotz S., Gospodarka materiałowa. Poradnik praktyczny (Materials Management. Guidebook), Wyd. Alfa-Weka, Warsaw 1998

${ }^{5}$ ibidem, p. 8
} 
organize the processes, to the benefit of the client, so that the customers are satisfied and buy goods from our company. On the other hand, the fact that logistics services providers are actually only an intermediaries, who not necessarily identify themselves with the company's goals, might cause that they are not intent on satisfying the customer. This situation is dangerous and might lead to losing positive image by the company, which, in consequence, negatively impacts on the sales. On the other hand, despite some threats of using outsourcing, proper operation of companies (especially those operating in global markets) without using logistics services is actually not possible. This happens because one company is not able to specialize so much as to become a leader in production, marketing and logistics and other areas of operation. The competition between supply chains has become so strong that it is necessary to look for new solutions which enable to gain competitive advantage ${ }^{6}$. One of them is outsourcing in reverse logistics.

Typical activities of reverse logistics include processes which the company uses to collect worn out, damaged, unwanted or outdated products and the processes of packaging or sending materials from final user to manufacturer.

If the products are returned to the company, the company has a variety of possibilities to handle them. If there is possibility to return a product to supplier at the full cost reimbursement, the company might choose this option as first. If the product has not been used yet, it can be resold to another customer or might be re-sold in the manufacturer's shop. If the product is not of full value to be sold, it is passed to the repair services company, which, after appropriate repairs and improvements will export this product to the market.

If a product can not be sold in current condition or if the company can considerably increase its price through renovation, recovery or processing of the product, the company can perform such activities before the product is sold. If the company does not perform such activities in its location, the intermediary companies, cooperating on the basis of contract or through outsourcing, can be involved in this procedure or the product might be sold immediately to the company which renovates, recovers or processes products.

After performing these activities, the product might be sold as a renovated product or a processed product but not as a new one. If the product can not be renovated due to its bad condition or the environmental law does not permit to do this, the company can try to use this product at the lowest possible cost of production. The reverse logistics might involve a wide variety of activities. These activities might be performed in the following way: goods, materials, product or package in reverse flow return from end user or other user in distribution channel such as retailer or distribution centre. Independently of its final designation, all products in the reverse flow must be stored and sorted before despatch to the final destination locations.

If a product gets to reverse logistics flow from the customer, this might be a damaged product. The customer might also only think that the product is damaged while it is actually in good repair. This might result from customer's lack of knowledge on using a particular product.

If a product has not reached the final stage of its life, the customer may return the product to the service shop or directly to manufacturer. If the product has reached its final stage of usability, the customer may, in some cases, return product to manufacturer and a producer might use it in an appropriate way or to recover materials.

\footnotetext{
${ }^{6}$ P.B. Schary, T.Skjott-Larsen, Zarzqdzanie globalnym tańcuchem podaży (Management of Global Supply Chain), Wyd. PWN Warsaw 2002
} 
If a product is returned by the partner in supply chain, this occurs because the product has not been sold or the partner wanted to get rid of it. The product might also reach its final stage of life or final stage of regular sales season. The product might also be damaged or destroyed.

Reverse logistics is strategically used mainly to enable users of a traditional channel - such as retailers and wholesalers - to take opportunity of reduction of risk of buying products which might not sell perfectly. For example, a company might create a software which controls the number of returns for various products depending on different elements which characterize particular groups of products ${ }^{7}$.

Strategy which involves possibilities of reverse logistics considerably impacts on company's cost. The goal of almost each business is to attach its customers to the company so as the customer do not change the supplier. There are many methods to build relationships which make it difficult to the customer and which put customers at risk of losing the benefits in case they change suppliers. An important services which supplier can offer to the customer is to give opportunity to return not sold or damaged products immediately, which credits customers on a temporary basis.

Initiation of reverse logistics might be a strategic response to a situation of growth in competitive environment. Most of sellers and manufacturers have in recent years liberalized its policy of returns, due to the pressure from competitors. The companies still believe that the satisfied customer and ensuring possibilities of returns of unwanted products (which, according to the customers do not match their needs) are essential.

Cooperation in reverse logistics might concern its all aspects and activities such as collective planning, forecasting, design or marketing. This is essential due to the following benefits resulting from cooperation:

- possibility of integrated information;

- possibility of tracking and monitoring of events in supply chain;

- improvement in clarity in supply chain;

- possibility of managing the processes through corrective actions.

\section{Advantages of reverse chain outsourcing}

Reduction of costs connected with logistics is justified in case when it leads to increase in profits. Currently the most popular form of saving in logistics departments is outsourcing of supply chain. Such a decision might impact on flows and financial results.

First remarkable advantage is cumulating of commitments in the moment of the whole process of delivery. The settlements between individual suppliers are transferred to a logistics companies. The ordering entity gets the elongated deadline for payments and better opportunities to negotiate the price. The financial sources released in such a way increase its current assets.

In order to execute the logistics processes it is necessary to involve fixed assets with a considerable value. They are mainly used for maintenance of distribution systems. In such systems, the resources of enormous value are employed - warehouses, distribution centres, local storage areas. The physical flow of goods between points of sale is realized also by the fleets which usually belong to the companies themselves and not to the specialized service providers. More and more often a tendency appears to rationalize distribution systems, e.g. through using

\footnotetext{
${ }^{7}$ J. Nowakowska-Grunt, L. Jahnatek, Systemy ERP jako determinanty zarzqdzania łańcuchem dostaw żywności na przyktadzie ZT Kruszwica S.A, Mat. Konferencyjne WSB W Poznaniu, Chorzów 2007
} 
specialized services of suppliers of complex logistics solutions. This tendency arose from the popular belief that actual cost of financing of investments with fixed assets is sometimes much higher than the cost generated by the investment.

Another element which makes companies to abandon the attempts to extend fixed assets connected with logistics is the efficiency of their use. The logistics companies show higher flexibility in terms of warehousing facilities and fleet. Another advantage of subcontracting the supply chain maintenance to a specialized logistics company is a fact of savings, which appears as a result of liquidation of the transport/warehousing departments. Such units, apart form labour costs, absorb a lot of expenditures connected with purchase of software. A drawback of most of these systems is the price and lack of possibilities to be used in other departments. Logistics companies also make use of advanced systems, however, the cost of their purchase might be spread among a few clients.

Among numerous benefits connected with a supply chain outsourcing, having influence on financial standing of the company, the most important include:

1. Increase in current assets through more profitable form of liabilities and opportunity to achieve time compression.

2. Better use of fixed assets.

3. Reduction in costs not connected with core activities in the company.

\section{Bibliography:}

1. Duck O., Schotz S., Gospodarka materiałowa. Poradnik praktyczny, Wyd. Alfa-Weka, Warsaw 1998

2. Nowakowska-Grunt J., L. Jahnatek, Systemy ERP jako determinanty zarzadzania łańcuchem dostaw żywności na przykładzie ZT Kruszwica S.A , Mat. Konferencyjne WSB W Poznaniu, Chorzów 2007

3. Rydzkowski W., Ustugi logistyczne, Instytut Logistyki i Magazynowania, Poznań 2004.

4. Schary P.B., T.Skjott-Larsen, Zarzqdzanie globalnym łańcuchem podaży, Wyd. PWN Warsaw 2002

5. Szczepaniak T., Transport i spedycja w handlu zagranicznym, PWE, Warsaw 2002.

6. www. RLmagazine.com 